\title{
Itinéraires Itinéraires
}

Littérature, textes, cultures

\section{The Translator as Literary Critic? Alexandre Vialatte's Battling le Ténébreux Through the Eyes of the Translating Subject}

Le traducteur en tant que critique littéraire? Battling le ténébreux

d'Alexandre Vialatte à travers le regard du sujet traduisant

\section{Frances Egan}

\section{OpenEdition}

\section{Journals}

Electronic version

URL: http://journals.openedition.org/itineraires/4894

DOI: $10.4000 /$ itineraires.4894

ISSN: 2427-920X

\section{Publisher}

Pléiade

\section{Electronic reference}

Frances Egan, «The Translator as Literary Critic? Alexandre Vialatte's Battling le Ténébreux Through the Eyes of the Translating Subject », Itinéraires [Online], 2018-2 et 3 | 2019, Online since 20 February 2019 connection on 18 June 2019. URL : http://journals.openedition.org/itineraires/4894; DOI : 10.4000/ itineraires.4894

This text was automatically generated on 18 June 2019.

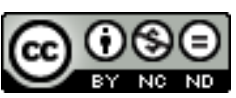

Itinéraires est mis à disposition selon les termes de la licence Creative Commons Attribution - Pas d'Utilisation Commerciale - Pas de Modification 4.0 International. 


\title{
The Translator as Literary Critic? Alexandre Vialatte's Battling le Ténébreux Through the Eyes of the Translating Subject
}

\author{
Le traducteur en tant que critique littéraire? Battling le ténébreux \\ d'Alexandre Vialatte à travers le regard du sujet traduisant
}

Frances Egan

1 As I translated Alexandre Vialatte's 1928 novel Battling le ténébreux ou La mue périlleuse (Vialatte 1982) into English, I found myself spending an extensive amount of time on the title. Destabilised by the language switch, I followed "Battling" through the old German "Batteln" and the English Battling Butler, "ténébreux" via Amadis de Gaula to the beau ténébreux, stopping at Walter Scott's Ivanhoe (1820), Nerval's El Desdichado (1854) and the Byronic hero, and finally "mue" through breaking voices to a metafictional coming-ofage. As my translation meandered and thickened, I realized that I had lost interest in fixing the text's meaning in English. I wanted to find a title (the temptation the challenge posed was too strong), but the end result had quickly become less important than the journey. Why I chose this word, why such and such interpretation was correct, why one should foreignise (Venuti 2012: 15-20) and not domesticate-these questions paled behind the translational encounter itself.

2 I myself am a non-native speaker of French: someone for whom English is home and French will always be other. For whom modernism was first about Virginia Woolf, Ernest Hemingway, William Faulkner. For whom the strangeness of French is directly in comparison to the workings of English, its defamiliarisation rich and poetic and possible. In the case of translating Battling le ténébreux, how can I hope to inhabit Alexandre Vialatte's subjectivity, spouting from the body of a white male, in the inter-war period, from a translator of Franz Kafka and later Friedrich Nietzsche, fan of E.T.A. Hoffman, friend of Henri Pourrat? And how can I write it, from my own position, a woman 
brandishing an English of the twenty-first century, tinged with Australian culture, and a literary memory of English and American modernism?

But this is not an essay on how to reproduce the author's intentions in translation; it is rather one proclaiming the value in how the translator fails to do so. What if the negotiation between original and translation, French and English, 1928 Auvergne and 2018 Melbourne, man and woman, German-French translator and French-English translator, did not pose problems but offered fodder for analysis. It seems to me that the very instance of translating, from its inter-lingual, inter-subjective space, can tell us more about the literary text than any finished product. For the in-between from which the translator works is "bewildering and aesthetically fertile" (Englund 2013: 1); it warrants our attention. Where imaginary can be broadly defined as an "interface between the subjective position and the world, as a register of thought or as the universe of images and signs, texts and objects of thought" (Clüver, Engelberts, and Plesch 2015: 11), the translator's negotiation with the writer's language draws upon an important translingual, transcultural imaginary. So, I wonder, how can we engage with the translating subject, and her imaginary, as a tool for literary analysis?

\section{The Subject in Literature}

When we talk about text we talk about voice, authorial identity, signature, selfexpression; literature comes from the writer's personal encounter with words. In translation, we continue to talk about the author's subjectivity. Crouching behind text and author, the translator hopes not to enter the text but rather to smooth the way for a new reader to receive the original author's expression (Nikolaou and Kyritsi 2008: 20). At a superficial level, the result is quite neat: two texts, copies, one subjectivity. But there are flaws. The translator's imagination is in there somewhere, picking an approach, making decisions, transforming the original. And if we ignore her presence, we miss some of the subjective magic of the process.

Where translation is about effacing the self, writing is about finding it, or even forming it. Literature is the subject becoming in language. Speaking of the "me," Maggie Nelson says that "writing has been the only place I felt it plausible to find it (whatever 'it' is)" (2015: 47). For John Eakin, story constitutes the self (2008: 2), and for John Sturrock "a life storied is a life made meaningful" (1993: 20). Joan Didion claims that we need stories to live, and for Émile Benveniste, language is not communication, it is living (1958: 259). In fact, in Benveniste's theory, there is no subject without language. It is the words-what the subject says about him or herself, materializing the individual in a public language, exterior to the self-that makes the subject. Picking up from Benveniste, Meschonnic says that the subject is formed, or just is, by meeting society and history in discourse. Literature is then the subject's medium in a battle against the unknown (Meschonnic 2009: 33). The individual gains definition through self-expression, through making inner feeling, thought, sensation, experience-or perhaps fantasies, dreams, imagined worldouter. And humanity battles the questions of existence through this collective movement of thought, literature, poetry, theory, discussion. Meschonnic labels this eternal and everincomplete process 'rythme': individual subjects come together in an evolving dialogue, gradually filling the unknown with words (2009).

6 Subjective experience makes literature what it is precisely because it does not transcribe smoothly into words. Writing encounters obstacles and deformation rather than 
reproduction and completion; there remains an inevitable gap between one's thoughts, body, feelings, ideas and the materiality of language. This prevailing material difference between self and language renders writing alienating, for literature is Other, a public thing, never quite of one's own. Yet therein lies its value. Writers look for themselves through the otherness of language. Lyric poetry is "the discourse of the constitutive alienation of the subject in language-the alienation that constitutes the genesis of the "human"' (Blasing 2007: 13). The subject is never fully defined, objectified, stable, but continues to become in literature, changing with time and context-a becoming in which one never becomes (Deleuze and Parnet 1996: 8-16). Nevertheless doomed to try, we are forever drawn to language and continue to write stories, make material the experience of being, use the encounter with words.

In the case of translation, the subject meets another in language. In this battle against the unknown through expression, translation equally wrestles with words for meaning, the alterity not one war but multiple (Nouss 2007: 246). The translator endeavours to inhabit the author's subjectivity, and write another's becoming in language, in a constant battle with otherness where she tries to understand, and reproduce, but not to make her own. Alexis Nouss finds parallels between this becoming in language and translation. Discarding traditional theories of translation which do not take into account the eternal nature of the unclean exchange, Nouss posits translation as métissage, as always both, never finished, cross-fertilising, unstable and transforming, in a constant position of "and" (2007: 247-48). This enriching movement represents the ongoing formation of the subject in language in an encounter with alterity that enables recognition and meaning. Since the Romantics, who famously appropriated the other in order to grow the self, translation has often been talked about in terms of self and other. Following postcolonialism, translation studies replaced appropriation with the recognition of other as other (Berman 1984: 88) or not simply other but as a trace within the self (Spivak 1993: 179). Today, instead of binary and unproductive categories, translation is considered the "mode of connection and exchange" (Karpinski 2012: 29) between subjects. Contemporary characterisations of translation are marked by plurality and indeterminacy. Since we can never hope to tell the truth about another text (Scott 2006: 33), the translator, working from the original author's intention, multiplies and extends the text. Translation engages with another subjectivity but does not eliminate it; the process is then one of Meschonnic's relation not transfer, of Deleuze's meeting not becoming, of métissage, confrontation and dialogue (Laplantine and Nouss 1997: 37). It is the encounter between subjects in language that is interesting.

With text as materialisation of the subject, Lucie Bourassa suggests that a study of literature is an "anthropology of language" (2010: 14). Susan Stewart sees poetry as the revealing threshold between individual and social existence (2002: 1), and Meschonnic's rhythm "organises being" and serves as a "historic realization of life"2 (Snauwaert 2012: $\S 17)$. In such a study of literature, translation offers a manifestation of the process, of the becoming. It is the formless form, the evidence of irresolution, of "and"-Deleuze's entre les deux, devenir, rhizome, ET (1996). Translation reveals the movement that is integral to the formation of self, and of text (Karpinski 2012: 29). Yet we rarely use this unique perspective for purposes other than reproducing the original. All the flow, mess, possibilities and ideas must be contained and fixed in writing the author's intention in a new context. But where each translation is a fleeting and highly individual anchoring of ideas, the interest seems rather in the very movement. The plurality and indeterminacy 
which present obstacles to translation reveal the poetics of the individual's encounter with alterity in language. By not engaging with the translating subject, and articulating this dialogue, we miss the potential of a translational approach to literary analysis.

\section{Or Outside of Literature? The Modernists Unhoused}

10 I started thinking about the translator's imaginary working on Vialatte's text. Vialatte was himself a translator and is perhaps better known for his translations of Franz Kafka into French than for his own fiction; he actively introduced the writer to the French literary scene. Born in the Auvergne, Vialatte lived between France and Germany, spending the six years prior to writing Battling, from 1922 to 1927, predominantly in Germany. In this time, he translated Bertolt Brecht's Trommeln in der Nacht (Tambour dans la nuit) and a novella by Kasimir Edschmid, wrote an article on Hesse, professed his admiration for Thomas Mann, and discovered Kafka. He also worked as a bilingual writer for journals and magazines, an editor for the French-German magazine La Revue Rhénane, and begun a novel, the roman rhénan, in which the Auvergne was foreign and Germany familiar. It seems the two places and languages swirled around in Vialatte's work and his thinking; home had become a confusion of neither and both.

11 This type of translingual imaginary flourished in the inter-war period and was closely linked to the modernist crisis of meaning and its accompanying experimentation. The period was one of immense flux, characterised by the writer-in-exile who George Steiner memorably described as an unhoused wanderer across languages. Never had there been such incidence of both voluntary and enforced emigration, and never so temporarily, with such ease of return. For the first time, emigration or expatriation was often equated with coming home (Englund 2013: 6), with coming and going, and with bringing one's home elsewhere. More than before, one could be at home in many places or none, in a mesh of cultures, languages and literary traditions.

Estrangement of writer and language had become not only typical but also vital. In Languages in exile, Englund writes that:

No great writer can remain a merely local mind, unwilling to question the relevance of the particular places from which he writes, or to extend the radius of their presence, or to estrange and exile himself, so to speak, at some point in his search for metaphor, from immediate circumstance. (2013: 280)

13 Vialatte himself describes his experience of living elsewhere as difficult but illuminating:

I do not believe myself made to live forever in France. Living abroad will stay dear to me. You learn a lot, and fifteen years in France does not, I think, go as far towards inner enrichment as five years anywhere else; you pay a heavy price perhaps for what you learn, but you live more. (Vialatte 2004: 44) ${ }^{3}$

The encounter with a different language, culture, and place meant an encounter with oneself in another language. Identity and meaning had become in-dissociable from language where writing served as the drawing board: the disorienting and generative meeting between self and other (Englund 2013: 1). In this space, language came alive. Writers such as Virginia Woolf and Marcel Proust championed the positive effects of a foreign language or a foreignness of language. Russian poet Marina Tsetaeva, writing to Rilke in 1926, claimed that, to write poetry, one had to reinvent one's maternal language from multiple languages. The Russian formalist Victor Shklovsky's "defamiliarisation" describes this phenomenon (Lemon and Reis 1965). His adage "art exists that one may 
recover the sensation of life" (12) draws on a foreignness of language to perceive the world anew. Viewing language as Other invites an experience of literature that is plural and open, beyond the everyday, just as art demands.

This in-between permeates the novel Battling. At first glance, the text follows a neat postromantic tradition. Descending from Alan-Fournier's Le Grand Meaulnes (1913), it is a coming-of-age tale wrapped in the pretty package of a récit poétique (Tadié 1978). The protagonist Battling, a dreamer unfit for this world, obsesses over an unattainable woman and seeks meaning beyond ordinary life. But on closer inspection, things feel a little offkey. The text sits awkwardly in its French literary tradition, engaging with modernité but pulled askew by German Romanticism. Battling's foreign nickname marks him an outsider, unhoused from language, and his French-German love interest Erna Schnorr sits incongruously in her role of older object of desire. Far from the classic French beauty come to inspire the young man, Erna is a strange concoction of national stereotypes and aesthetics which work to confuse her beholders. The language of the text is fragmented and uncomfortable; it seems eager to escape the confinement of its French words and flat white paper.

\section{The Translator's Task}

16 Where the writer's translingual imagination has a long history of cultivating creativity (Kellman 2000), the translator's has traditionally been ignored outside of a means to the target text. However, theory points to the value in a translational approach to a study of literature. In the early 1920s, Walter Benjamin famously revolutionized the translator's task, presenting it not as communication but as a sophisticated exploration of poetics (Benjamin [1968] 1999: 70). In his transcendental theory, the original text is itself incomplete; each translation adds another fragment to a greater, mythical whole. His ideas originated with German Romanticism where meaning was elusive, but the fundamental complementarity of languages could bring one closer to it:

Meaning is never found in relative independence, as in individual words or sentences; rather, it is in a constant state of flux-until it is able to emerge as pure language from the harmony of all the various modes of intention. (Benjamin [1968] 1999: 75)

Rather than trying to discover and transfer the meaning of a text to a new audience, translation thrives in that element of literature which is "the unfathomable, the mysterious, the "poetic"' (70). Translating a text offers a glimpse of the ideal and fosters the growth of those languages that it acts between.

Just as Benjamin's idea of translation strives towards a pure language, forever out of reach, the German Romantics considered translation a meaningful journey through one's imaginary (Raimondo 2016). The modernists met themselves in another language to find an outlet in the very lack of stability and singularity; the Romanticists saw these identities as pieces of a greater puzzle. Fascinated with the self in art, translation was for them an exploration of the unknown via another personality, familiar yet strange. The possibilities of oneself in a foreign language offered ideas and words beyond the everyday, bringing one closer to the inconceivable borders of the self, the edges of the inexpressible and the mysterious otherness around. Through this labour of the imaginary, the translator could work towards a greater whole, using previously latent resources and mapping previously un-representable areas. Vialatte was attracted to 
German Romanticism's exploration of a dark and mysterious imaginary. He described himself as inhabiting the fiction he translated, writing in his letters, in 1924: "I feel like I am living in a Kafka novel" (Vialatte 2004: 24). ${ }^{4}$

Such spiritual journeys are not so fashionable anymore, but the Romantic's labour of the imaginary nevertheless has contemporary application. While the Romantics yearned for translation to take them beyond language, current theory at least allows that translation bring something Other to the specific individual, within a specific context. Translation sparks a search within the translating subject. By rummaging through one's own consciousness and one's literary imaginary for the words of another subject, new possibilities spring, new manners of thinking and expressing arise in oneself (Laplantine and Nouss 1997: 36). Tim Parks describes this internal exploration in translation: "every text, original or translation, is carved, or conjured out of this precariousness: a thousand sensations and pressures, a surface buzz of words-the consciousness [...]" (Parks 1998). As the source text filters through a different voice and language, it creates a pool of possibilities in the target language which in turn stimulates and inspires the movement of ideas (Raimondo 2016).

The creative destabilisation of translation is not only inter-subjective but of course interlingual. Like the modernists, the translator is unhoused from language. Never fully at home, she is rather an acrobat in mid-air (Woolf 1987: 44), the words around thick and strange. Untameable but malleable, language is here a tool with which to construct a writhing beast, some of it self, some of it other. The distance of the translator's estrangement also enables perspective. Writing about being between French and German, Heinz Wismann discusses the rich sense of otherness one has when neither language is home anymore: "as soon as you move 'between', you are faced with two alterities, since the origin becomes other too" (2012: 39). ${ }^{5}$ The in-between is not indecision, but the capacity to be and feel both, from outside of their grasp-not identification but reflexivité (45). The translating subject, hovering untethered, can see the becoming in language.

21 As a tool for literary analysis, translation shares commonalities with comparative literature wherein both take place in the 'and' zone (Bermann 2009). Where the comparatist works between two novels, for example, the translator works between "Brot" and "pain," drawing meaning from the similarities and differences (443). Translation itself, as the smooth transfer of equivalents, is not very interesting. It is rather the untranslatable, the non-translation, the back and forth, multiplicity and ambiguity that warrants attention (Apter 2013: 4; Cassin 2004: xvii). In the "and," seemingly clear statements become ambiguous, assumed meanings questionable, one's thoughts, feelings, ideas, sensations, suddenly multiple, bipolar, complex. Translation spouts questions and confusion where superficial first impressions of the text offered clarity (Rose 1981: 3). Flitting between original and translation then offers a unique perspective from which to study literature.

\section{Negotiating the In-Between: A Battle with Darkness?}

So how might I translate this title-Battling le ténébreux ou La mue périlleuse-into English? What type of subject should Battling be? Quixotic, brooding, melancholy, dark. And what type of journey is this mue? Rocky, wavering, shaky, perilous, precarious. Transformation, coming-of-age, sloughing, metamorphosis. The foreignness of "Battling" led me to the earlier discussion on Vialatte's translingual imaginary and the modernist crisis of 
identity. For why give your character such a nickname? Should he even be "Combattant" in English? The name "Battling" in French introduces a fragmented subject, lost in translation, seeking exile in the defamiliarised language of the text.

Despite this code switch, the epithet in the French is quickly apparent and announces the Romantic hero, that "beau ténébreux." Battling the melancholy, the brooding, the Byronic hero. I am tempted to see Byron's contradictions behind Vialatte's character. The text tells us that Battling's nickname is for "his look both heavy and supple of a peaceful brute"; , he embodies the inner conflict made famous by Byron's protagonists. At the same time, a French reader will almost invariably hear Gérard de Nerval's "ténébreux" behind the title. Nerval's famous poem El desdichado begins "Je suis le ténébreux": Battling the dark one, the saturnine, the gloom. ${ }^{7}$ While this line appears at first so definitive, the identities in fact go on and on: “- le Veuf, - l'Inconsolé, / Le Prince d'Aquitaine à la Tour Abolie." Nerval's ostensibly self-affirming poem is precisely the opposite: a representation of division and confusion. Moreover, Nerval's subject is similarly translated, a knight of trans-European origins. The title El Desdichado introduces Spanish chivalry and memories of Don Quixote tilting at windmills. Nerval apparently borrowed the title from Walter Scott's Scottish knight in Ivanhoe, modernising those adventurous and heroic battles with an internal and dream-like war of the self. ${ }^{8}$ Thinking about Nerval's poem in English also calls to mind T.S. Eliot's The Waste Land wherein he quotes: “ Le Prince d'Aquitaine à la Tour Abolie." These fragmented and translingual subjects keep piling up. But perhaps my habitus in Anglophone literature emphasises the alienated identities in Battling. Mine is an admittedly modernist reading of a text that has never been classified as such in French.

And what about the gerund "battling" that an English reading reveals in the title? As well as the epithet, there lurks a fight against something dark and mysterious, beautiful and sad, in Vialatte's title. Perhaps Battling the melancholy is best then, since "melancholy," as an adjective and noun, is open for some ambiguity. I like too that modernist melancholia leads me to the prose of sadness. This is a nostalgic novel about a knight's existential angst, but it cannot ignore the inter-war crisis of representation with its accompanying poetic haze. A battle with words against darkness?

Or a little alternative for the reader: La mue périlleuse. The novel's subtitle most obviously refers to the character Battling's fraught coming-of-age. "Mue" is first defined as the renewal of skin, hair or feathers due to growth, age, or living conditions (Larousse). Sloughing, moulting or shedding in English. In humans, the term also refers to one's coming-of-age and, in boys, the moment in puberty when one's voice breaks. Battling is uncomfortable in his own skin. His strong body and brutish physicality are at odds with his sentimentality, his Romantic ideas of the world conflict with his inner desires and modern vulgarity. The perilous coming-of-age. Any adjective along the precarious, dangerous, shaky lines sounds awfully long and clunky beside "mue périlleuse." I want to write "shaky" for the hint of a wobbly voice. But that does not sound right either. The precarious transformation, metamorphosis. "Metamorphosis" tempts me with its wink to Kafka and its associations with animalism and evolution.

Finally, this "mue" is also the text's. The term figuratively designates change at a societal level such that Battling's alienation and dark quest for identity represent the text's search for a modern subject fit to inhabit the violent and meaningless inter-war period. By way of the beau ténébreux, Vialatte enters a tradition of writers and artists searching for the self, in a battle with words against the unknown. In this inter-war period, such a 
pursuit fittingly finds its expression in a text torn between German romanticism and French modernité, between pre-war nostalgia and post-war reality, emanating from the translator's imaginary.

Any translation of Battling le ténébreux ou La mue périlleuse into English is incomplete; it upsets me with its flaws and its lacks. I want the title to be all things, but of course it never will. Translation is only a temporary fix, a momentary reconciliation that can always be altered and re-interpreted. Retranslation alone is evidence of our individual, temporal, contextual response to literature where, irrespective of translation, even the original language wavers and mutates. My brief analysis of Battling's title aims to use the movement of text in translation, and the translator's rich encounter with language, for a process-driven, unstable study of literature which is the articulation of difference (Bhabha 2012: 2). Splashing about in the in-between and in the moment of non-translation, the ambiguities, inconclusiveness and contemporary potentiality of the literary text come to light. In this case, grappling with Vialatte's voice in nineteen-twenties French, I am Woolf's acrobatic translator who flies from bar to bar and experiences the thrill of the thin air in-between; dangerously high and untethered (Davison 2015: 76), I make sure to document the flight. Christopher Isherwood famously wrote, in A Berlin Diary:

I am a camera with its shutter open, quite passive, recording, not thinking. Recording the man shaving at the window opposite and the woman in the kimono washing her hair. Someday, all this will have to be developed, carefully printed, fixed. (2008: 1)

What if we, through the translator's imaginary, show the camera with its shutter open. Not passively of course, but rather consciously subjective-let us express the changing scene in front of the camera, before we develop the translation.

\section{BIBLIOGRAPHY}

Apter, Emily S., 2013, Against World Literature: On the Politics of Untranslatability, London, New York, Verso.

Benjamin, Walter, [1968] 1999, Illuminations, edited by Hannah Arendt, translated by Harry Zohn, London, Pimlico.

Benveniste, Émile, 1958, De la subjectivité dans le langage, Paris, PUF.

Berman, Antoine, 1984, L'Épreuve de l'étranger : culture et traduction dans l'Allemagne romantique, Paris, Gallimard.

Bermann, Sandra, 2009, "Working in the And Zone: Comparative Literature and Translation," Comparative Literature, vol. 61, no. 4, p. 432-46.

Bhabha, Homi K, 2012, The Location of Culture, Oxford, Hoboken, Taylor and Francis.

Blasing, Mutlu Konuk, 2007, Lyric Poetry: The Pain and the Pleasure of Words, Princeton, N.J., Princeton University Press. 
Bourassa, Lucie, 2010, "Articulation et rythme : matière, pensée et création dans le discours," Intermédialité: Histoire et théorie des arts, des lettres et des techniques, no. 16, p. 185-206, [Online], https://id.erudit.org/iderudit/1001962ar, accessed 4 January 2019.

DOI: $10.7202 / 1001962 \mathrm{ar}$

Cassin, Barbara, 2004, Vocabulaire européen des philosophies : dictionnaire des intraduisibles, Paris, Le Robert, Seuil.

Clüver, Claus, Matthijs Engelberts, and Véronique Plesch, 2015, The Imaginary: Word and Image, Leiden, United States, Brill.

Davison, Claire, 2015, "Bilinguals and Bioptics: Virginia Woolf and the Outlandishness of Translation," in J. Dubino et al. (eds), Virginia Woolf: Twenty-First-Century Approaches, Edinburgh, Edinburgh University Press, p. 72-90.

Deleuze, Gilles, and Claire Parnet, 1996, Dialogues, Paris, Flammarion.

Eakin, Paul John, 2008, Living Autobiographically: How We Create Identity in Narrative, Ithaca, N.Y., Cornell University Press.

Egan, Frances, 2017, “Surrendering to the foreignness in Alexandre Vialatte's Battling le ténébreux ," TRANS - Revue de Littérature Général et Comparée, no. 21, [Online], http://

journals.openedition.org/trans/1549, accessed 4 January 2019.

DOI : $10.4000 /$ trans.1549

Englund, Axel, 2013, Languages of Exile: Migration and Multilingualism in Twentieth-Century Literature, Bern, Peter Lang.

Isherwood, Christopher, and Armistead Maupin, 2008, The Berlin Stories, New York, New Directions Pub.

Karpinski, Eva C., 2012, Borrowed Tongues: Life Writing, Migration, and Translation, Waterloo, Ont., Wilfrid Laurier University Press.

Kellman, Steven G., 2000, The Translingual Imagination, Lincoln, University of Nebraska Press.

Laplantine, François, and Alexis Nouss, 1997, Le Métissage : un exposé pour comprendre, un essai pour réfléchir, Paris, Flammarion.

Lemon, Lee T., and Marion J. Reis, 1965, Russian Formalist Criticism: Four Essays, Lincoln, University of Nebraska Press.

Meschonnic, Henri, 2009, Critique du rythme : anthropologie historique du langage, Lagrasse, Verdier. Nelson, Maggie, 2015, The Argonauts, Minneapolis, Graywolf Press.

Nikolaou, Paschalis, and Maria-Venetia Kyritsi, 2008, Translating Selves: Experience and Identity between Languages and Literatures, London, New York, NY, Continuum.

Nouss, Alexis, 2007, “Translation and Métissage,” in P. St-Pierre and P. C. Kar (eds), In Translation: Reflections, Refractions, Transformations, Philadelphia, John Benjamins.

Parks, Tim, 1998, “Prajapati,” London Review of Books, 19 February 1998.

Raimondo, Riccardo, 2016, "Le Démon fugitif de l'imagination. Propositions pour une traductologie comparée : Nerval et Baudelaire,” Nouvelle Fribourg, no. 2, [Online], http:// www.nouvellefribourg.com/archives/le-demon-fugitif-de-limagination-propositions-pour-unetraductologie-comparee-nerval-et-baudelaire/, accessed 4 January 2019.

Rose, Marilyn Gaddis, 1981, Translation Spectrum: Essays in Theory and Practice, Albany, State University of New York Press. 
Scott, Clive, 2006, "Translation and the Spaces of Reading," in E. Loffredo and M. Perteghella (eds), Translation and Creativity: Perspectives on Creative Writing and Translation Studies, London, New York, Continuum.

Snauwaert, Maïté, 2012, "Le rythme critique d'Henri Meschonnic," Acta Fabula, vol. 13, no. 6 (juillet), [Online], http://www.fabula.org/acta/document7129.php, accessed 4 January 2019. Spivak, Gayatri Chakravorty, 1993, Outside in the Teaching Machine, New York, London, Routledge. Stewart, Susan, 2002, Poetry and the Fate of the Senses, Chicago, University of Chicago Press.

Sturrock, John, 1993, The Language of Autobiography: Studies in the First Person Singular, Cambridge, New York, Cambridge University Press.

Tadié, Jean-Yves, 1978, Le Récit poétique, Paris, PUF.

Venuti, Lawrence, 2012, The Translator's Invisibility: A History of Translation, Hoboken, Taylor and Francis.

Vialatte, Alexandre, 1982, Battling le ténébreux ou La mue périlleuse, Paris, Gallimard.

Vialatte, Alexandre, 2004, Correspondance Alexandre Vialatte - Henri Pourrat : 1916-1959. 3. Lettres de Rhénanie II : Juin 1924-Décembre 1927, Clermont-Ferrand, Presses universitaires Blaise Pascal.

Wismann, Heinz, 2012, Penser entre les langues, Paris, Albin Michel.

Woolf, Virginia, 1987, The Essays of Virginia Woolf, Vol. 4 (1925-1928), ed. by Andrew McNeillie, New York, Harcourt Brace.

\section{NOTES}

1. 1926 Buster Keaton film.

2. "Organisation du vivant"; "une mise en œuvre historique de la vie."

3. "Car je ne me crois pas fait pour habiter toujours la France. L'étranger me restera cher. On y apprend beaucoup, et quinze ans de France valent moins, je crois, pour l'enrichissement intérieur que cinq ans de n'importe où ; on paie peut-être un peu cher ce qu'on apprend, mais on vit davantage."

4. "Je me fais l'impression de vivre dans un roman de Kafka."

5. "À partir du moment où on s'installe 'entre', on a affaire à deux altérités, puisque l'origine devient autre elle aussi."

6. "Son allure souple et lourde à la fois de brute paisible."

7. Different English translations of Nerval's "ténébreux".

8. I follow the title's intertextuality even further in my article published in 2017 "Surrendering to the foreignness in Alexandre Vialatte's Battling le ténébreux."

\section{ABSTRACTS}

Historically, the translator has effaced herself to reproduce the author's voice and the original text. Recent research has rendered the translator visible in translation studies but less so in 
literary studies. I propose engaging with the translating subject and the translator's imaginary for the purposes of literary analysis. If literature is a product of the writer's personal encounter with words, at the threshold between individual and social existence, the translator's experience is uniquely inter-subjective. The wrestle for meaning between writer and translator, across times, languages, and cultures, warrants attention in literary studies. This article draws from my own experience translating Alexandre Vialatte's novel Battling le ténébreux ou La mue périlleuse (1928) into English. Instead of analyzing or justifying my reproduction of the original text, I articulate the obstacles to translation-ambiguities, cultural and ideological differences, intertextuality-for a study of the underlying intention of the original text and a vision of its potential afterlives today.

Historiquement, le traducteur s'efface pour reproduire la voix de l'auteur et le texte original. Les recherches récentes en traductologie ont valorisé la subjectivité du traducteur qui peine cependant encore à trouver sa place dans les études littéraires traditionnelles. Je propose d'utiliser la notion d'imaginaire du traducteur comme un dispositif critique pour l'analyse littéraire. Si c'est l'inscription du sujet dans le langage qui fait le texte, au seuil de l'individu et de la société, le traducteur profite de façon unique d'une expérience intersubjective. Le combat pour le sens en traduction qui engage les subjectivités, les langues et les époques mérite de l'attention dans les études littéraires. Cet article s'inspire de ma propre traduction anglaise du roman Battling le ténébreux ou La mue périlleuse (1928) d'Alexandre Vialatte. Au lieu d'analyser ou de justifier ma propre version du texte, au lieu de chercher à en démontrer l'exactitude, je me sers des obstacles de la traduction - les ambiguités, les différences culturelles et idéologiques, l'intertextualité - pour proposer une analyse littéraire qui soit en mesure de faire face à la subjectivité et à la complexité du texte littéraire et ses après-vies.

\section{INDEX}

Mots-clés: subjectivité, traduction, sujet traduisant, analyse littéraire, intraduisible, modernisme

Keywords: subjectivity, translation, translating subject, literary analysis, untranslatable, modernism

\section{AUTHOR}

\section{FRANCES EGAN}

PhD candidate en cotutelle, Université Sorbonne Nouvelle-Paris 3 (Prof. Claire Davison), ED514

Monde anglophone, The University of Melbourne (Prof. Véronique Duché), French Studies 